\title{
Egy ismeretlen „öserdö” a Kelet-Mecsekben: 25 éve felhagyott bükkös aljnövényzetének térbeli mintázatai
}

\author{
ORTMANN-NÉ AJKAI ADRIENNE', TÓTH ISTVÁN ZSOLT², SIROK ATTILA', NAGY DÁNIEL¹, \\ KULCSÁR PÉTER ${ }^{2}$, PARTOS KÁLMÁN ${ }^{3}$ \\ ${ }^{1}$ PTE TTK Környezettudományi Intézet, Ökológiai és Hidrobiológiai Tanszék, 7635 Pécs, Ifjúság útja 6. \\ ${ }^{2}$ Duna-Dráva Nemzeti Park Igazgatóság, 7625 Pécs, Tettye tér 9. \\ ${ }^{3}$ Mecsekerdő ZRt, 7623 Pécs, Rét u. 8. H-7624 Pécs, Ifjúság u. 6.
}

\begin{abstract}
Ortmann-Ajkal A., Tóth I. Zs., Sirok A., Nagy D., Kulcsár P., PARTOS K.: A scarcely known old-growth forest in Eastern Mecsek hills: Spatial patterns of the herb layer of a beech forest abandoned 25 years ago.

Abstract: A 130-years old beech forest stand (Helleboro odori - Fagetum) in Eastern Mecsek hills (Southern Hungary), abandoned 22-25 years ago, provides excellent opportunities for the study of spontaneous forest dynamics. In 2010 intensive studies started, iniciated by Mecsekerdő Zrt: repeating an individuum-based tree-stand survey of 1986-87, and a gridbased herb layer survey according to the Forest Reserve Protocol. In the herb layer 95 species were found, amongst them 14 protected ones, most of them in the hillside-hilltop ecotone. Most important are the more thousand exemplars of Doronicum orientale. More than $30 \%$ percentage of specialist and competitor species indicates a very good naturalness state, comparable with forest reserves.
\end{abstract}

Keywords: Helleboro odori - Fagetum, forest reserves, Shannon diversity, social behaviour types, protected species, Doronicum orientale.

\section{Bevezetés}

A új Erdötörvényben (2009) megkövetelt folyamatos erdőborítás gyakorlati megvalósítása új hangsúlyt ad a természetes erdődinamikai folyamatok kutatásának. A gazdasági erdőkben lezajló folyamatok megértése céljából is elengedhetetlen, hogy feltárjuk a természetközeli és/vagy felhagyott és gazdasági erdők szerkezete és müködése közti alapvető hasonlóságokat és különbségeket (Somogy 2002). Ilyen hosszútávú kutatására hazánkban szinte kizárólag az erre a célra kijelölt erdörezervátum-magterületeken van lehetőség (HoRVÁTH és BoRHIDI 2002, HORVÁTH és MTS. 2012), amelyek a hazai erdőtakaró mindössze 0,21 \%-át teszik ki (BARTHA és EszTó 2002).

Kelet-mecseki mintaterületünk egyes erdőrezervátumokhoz hasonlítható lehetőséget biztosít a bükkösök spontán erdődinamikai folyamatainak tanulmányozására. Brang (2005) felhívja a figyelmet arra, hogy az erdőrezervátumokban kapott eredmények csak számos korlát figyelembevételével alkalmazhatók a természetközeli erdőgazdálkodás referenciájaként. Vizsgált területünkön ezek a feltételek sok erdörezervátumnál jobban teljesülnek. A Kelet-Mecsek Tájvédelmi Körzetben, a Várvölgy északra néző oldalában található 140 éves, 25 éve nem művelt bükkös állomány a hasonló cönológiai besorolás, termőhely, erdőtörténet és térbeli közelség révén a közeli Máza, Szászvár és Váralja erdőrészletekben a Pécsi Tudományegyetem és a Mecseki Erdészeti Zrt együttműködésében megkezdett lékvágásos kísérletek (Csete és mts. 2012, Ortmann-né AJKAl 2012) alkalmas kontrollterülete lehet.

A Mecsekerdő ZRt Pécsváradi Erdészete kezdeményezésére a 2010. évben részletes felmérések kezdődtek (PARTOs 2010). A kutatások érdekében egyes erdőrezervátumokhoz hasonlóan $50 \times 50$-es pontháló került kiépítésre. Egy 1986-87-es egyedalapú faállomány-szerkezeti felmérést Partos Kálmán 2011-ben megismételt FieldMap müszerrel. A ponthálóhoz kapcsolódóan részletes aljnövényzet-felmérés készült (SIROK 2011, TóTH ET AL. 2012), és madármonitoring-vizsgálat is zajlik a MME Mindennapi Madaraink Monitoring programjához kapcsolódva (Laczik és Sebe szóbeli közlés). A PTE KTI Ökológiai és Hidrobiológiai Tanszékének munkatársai 2008-2009-ben részletesen felmérték a terület északi határát képező Várvölgyi-patak vízi makrogerinctelen faunáját (KÁLmÁN ET AL. 2010, MAUCHART ET AL. 2010, MÉHES ET AL. 2010, SzivÁK ET AL. 2010). A terület tájtörténetének kutatása is megkezdődött (MÁTÉ 2009, MÁTÉ és VARGA 2011). Jelen munkában a 2010-ben végzett aljnövényzet-felmérések eredményeiről számolunk be.

\section{Anyag és módszer}

\section{Vizsgálati hely}

A Magyaregregy 47A erdőrészlet a Kelet-Mecsek Tájvédelmi Körzetben, a pécsváradi erdészet kárászi erdőgondnoksága területén található (1. ábra). A szűk Várvölgy északra néző oldalán a völgyalji pataktól a határoló gerinc széléig 400-500 méter hosszan, 305-425 $\mathrm{m}$ tszf. magasság között húzódik. Alapkőzete mélytengeri üledék: dolomitos mészmárga. Az erősen málló kőzet egyes meredek helyeken a lágyszárú növényzet megtelepedését gátló csupasz törmelékfoltokat, sekély, rossz vízgazdálkodású talajt hoz létre.

Az erdő a Mecsek hasonló termőhelyein tipikus extrazonális, a régió-alávetődésnek köszönhetően létrejött szubmontán mecseki bükkös, Helleboro odoriFagetum Soó et Borhidi in Soó 1960 (BoRHIDI 2003). Faállománya nagyrészt bükkös, helyenként sok ezüsthárssal. A cserjeszint gyér, többnyire hiányzik. A völgyaljtól a tetőig felnyúló erdőrészletben a több mint 100 méteres szintkülönbség hatására erős mezoklimatikus gradiens észlelhetö, ami a növényzetben is kifejezésre jut. Az alsó részen, a patakhoz közel szurdokerdő-, a legmeredekebb, törmelékes részeken ezüsthársas törmeléklejtő-erdő jellegü, a tetőn - egy mintegy 20 évvel ezelőtti belenyúlás eredményeképp ezüsthárs-dominálta 


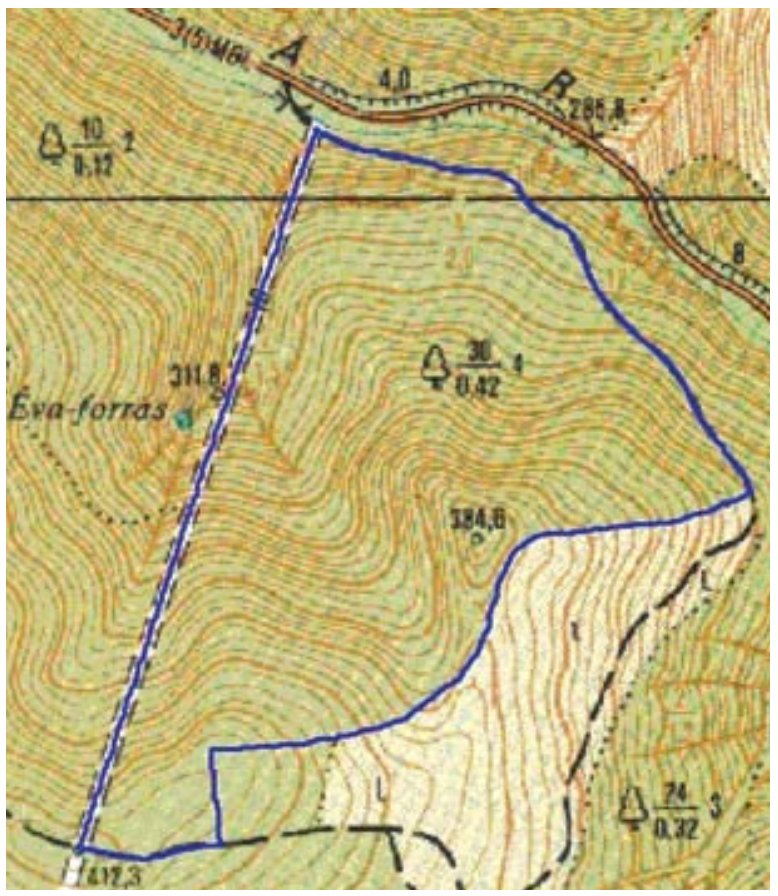

1. ábra: $A$ vizsgálati terület térképe

- tetőerdőbe megy át. Az erdőrészletben méretes fák kidőlésével megindult a spontán lékesedés, különösen a rendkívül esős tavaszú 2010. évben, így több olyan, különböző korú és méretű lék található, melyek később a lékvágásos kísérletek természetes kontrolljaként szolgálhatnak.

\section{Felmérési módszer}

$A z$ aljnövényzet felmérését a kitűzött ponthálóhoz kapcsolódóan végeztük. Tóth István Zsolt és Kulcsár Péter (DDNPI) tavasszal (május eleje) és nyáron (július eleje) a mintavételi pontokon 1,8 m sugarú $\left(10 \mathrm{~m}^{2}\right)$ körben fajlista és \%-os borítási adatokat vettek fel. Egy másik csapat (O. Ajkai Adrienne, Nagy Dániel, Sirok Attila) 2010 szeptemberében, az erdőrezervátumok aljnövényzeti felmérésére kidolgozott protokoll szerint (Ódor et al. 2008): pontonként $6 \mathrm{~m}$ sugarú körben $30 \mathrm{db}$ 0,5 $\mathrm{m}^{2}$ területü mintakör (2. ábra), fajlista és \%-os borítás) felvételezett, lehetővé téve az összehasonlítást bükkös erdőrezervátumokkal, pl. a közép-mecseki Kőszegi-forrás Erdőrezervátummal (SIROK 2011).

A felmérések adatait az ArcGIS programmal térinformatikai adatbázisba rendeztük. Értékeltük a teljes fajkészlet, borítás/fajszám arány, a védett és erdőtípusalkotó fajok, a szociális magatartás-típusok, Shannon diverzitás-index (Pásztor és Oborny 2007) térbeli mintázatait.

A mintavételi pontokat megjelenítő térképek az ERprotokollos felvételi adatokon alapulnak, kivéve a védett fajok térképét, ahol a Tóth-Kulcsár felvételezés adatait is beépítettük.

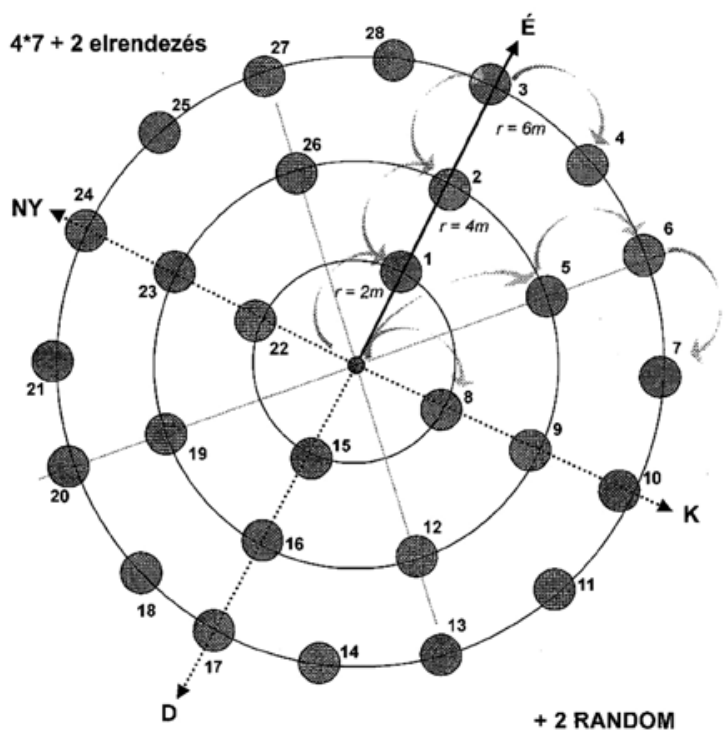

2. ábra: Az erdőrezervátum-protokoll szerinti 28+2 körös aljnövényzet-felmérés mintavételi elrendezése

\section{Eredmények}

\section{Fajkészlet}

A gyepszint közepes-nagy borítású, sok Fagetalia elemmel. Összesen 95 fajt találtunk a gyepszintben, ebből 14 védett. Jellemzőek a mediterrán jellegü fajok, pl. Tamus communis, Ruscus aculeatus, R. hypoglossum, Helleborus odorus, Lathyrus venetus, Asperula taurina. Felmérésünk szerint a kevésbé meredek részeken fajgazdag.

A legkisebb fajszámú pont 5 fajjal, míg a legmagasabb fajszámú 33 fajjal rendelkezik. Egy pontban találtunk ilyen fajgazdagságot amelyet a térképen középtájban láthatunk. A pontok többsége az 5-8 és a 13-17 fajszámmal bíró kategóriákba tartoznak. Magasabb fajszámot a lankásabb hajlatokban, völgytalpakban és a gerincen (ökotón helyzet) találunk, a közepes és kis fajszámú pontok a meredekebb lejtőkön helyezkednek el (3. ábra).

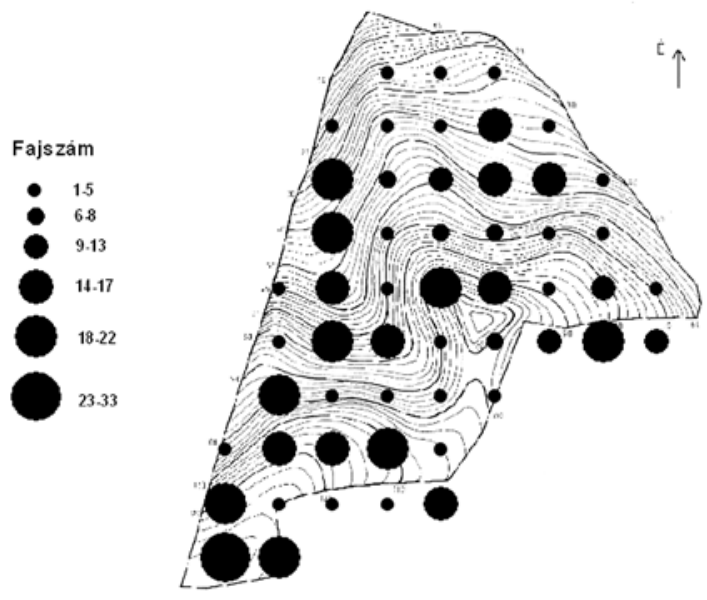

3. ábra: Fajszámok térbeli mintázata 


\section{EGY ISMERETLEN „ÖSERDŐ” A KELET-MECSEKBEN: 25 ÉVE FELHAGYOTT BÜKKÖS ALJNÖVÉNYZETÉNEK TÉRBELI MINTÁZATAI}

\section{Erdőtípus-alkotó fajok}

A márévári mintaterület erdőtípus alkotó fajai (MAJER 1962) (4. ábra) a következők: bükksás (Carex pilosa), sárga árvacsalán (Galeobdolon luteum), szagos müge (Galium odoratum), egyvirágú gyöngyperje (Melica uniflora), erdei szélfü (Mercurialis perennis), hegyi csenkesz (Festuca drymeia). Az egész erdőrészletre jellemző az üde termőhelyet jelző Galium odoratum, és a félnedvest jelző Galeobdolon luteum. Fenn a gerincen és alatta a nagyon meredek, sziklás oldalban Melica uniflora, Mercurialis perennis és kisebb mértékben Festuca drymeia jellemző. Utóbbi megjelenik a völgy aljához közelebbi részeken is, itt a szélsőségesen meredek oldal és erősen aprózódó alapkőzeten kialakuló sekély talaj miatt félszáraz a termőhely. Elsősorban az alsó régióban jelentkezik a bükksás (Carex pilosa), bár helyenként a gerincig is felmászik, együtt a Festuca drymeiá-val, A Mercurialis perennis ritkának mondható. A Melica uniflora DNy-i részen található meg, egy helyen domináns. A vizsgálati terület nagy részén (meredekebb részek) félszáraz és félnedves termőhelyek váltják egymást, a viszonylag lankásabb helyeken (északon és délen) egyértelműen félnedves típusú élöhelyek vannak. Az egyértelműen szárazabb területek a keleti részen találhatóak meg.

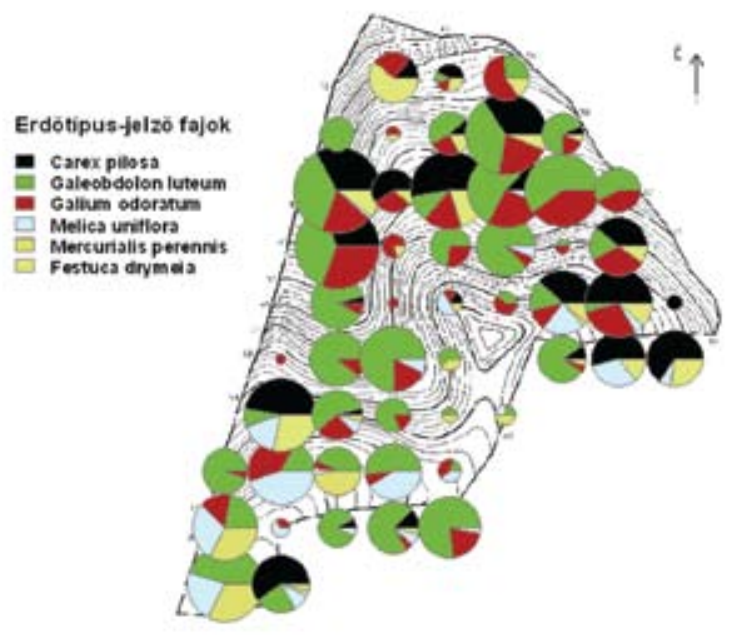

4. ábra: Erdőtípus-alkotó fajok térbeli mintázata

\section{Védett fajok}

A területen a körös felmérésében 9 , összesen 14 védett és ezeken felül 3 specialista faj került elő (5. ábra). $A$ védett és specialista fajok jellemzően a terület felső részén, a bükkös-tetőerdő átmeneti zónájában tömörülnek, a még zárt idős bükkös ezekben az „érdekes” fajokban szegény. A legfontosabb a gerincen a $10000 \mathrm{Ft}$ eszmei értékủ keleti zergevirág (Doronicum orientale) ezres nagyságrendű állományának előfordulása. Ez a faj hazánk 7 tájegységében fordul elő. A Keleti-Mecsekben 3 lelőhelye van, ez a hely eddig nem volt ismert kutatók előtt.
További védett fajok: Aruncus dioicus 2 tő, Asperula taurina subsp. leucanthera néhány foltban 400-500 tő, Cephalanthera damasonium 2 tő, Dryopteris dilatata 2 tő, Epipactis purpurata 1 tő, Epipactis helleborine 1 tő, Galanthus nivalis szórványosan és szálanként 100-200 tő, Polystichum setiferum 1 tő, Helleborus odorus 5-600 tő, Hepatica nobilis 100-200 tő, Lathyrus venetus föleg a felsőbb, ritkásabb részén 400-500 tő, Ruscus hypoglossum 10-20 példány, Ruscus aculeatus a felső, tetőhelyzetben levő kiritkult részen kb. $100 \mathrm{~m}^{2}$-es, vadcsapásokkal átvágott, összefüggő foltja él, Tamus communis felső nyíltabb részen 15-20 tő.

További nem védett, de érdekes specialista fajok: Festuca drymeia a bükkösök és gyertyános tölgyesek szubmontán övének jellemző, értékes faja, itt 15-20 helyen fácieszalkotó; Veronica montana, amely hazánkban, üde lomberdőkben szórványosan fordul elö, a felmért területen kb. 20-30 tő él.

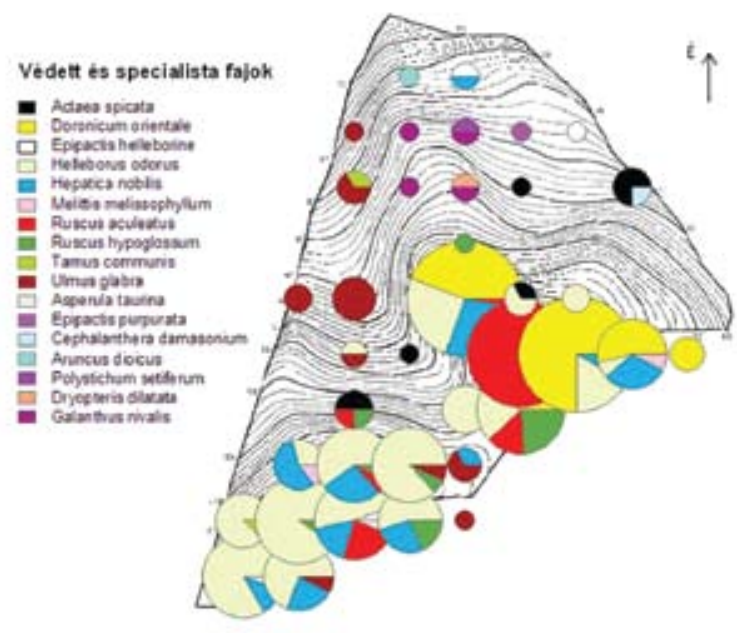

5. ábra: Védett és specialista fajok térbeli mintázata

\section{Szociális magatartástípusok spektrumai}

A szociális magatatástípusok (Borhidi 1995) megoszlása ép, természetközei állományt mutat (6. ábra) a specialisták és kompetitorok $30 \%$ feletti arányával. Ritka specialista fajok: Dryopteris dilatata, Ruscus hypoglossum; specialista fajok: Acer pseudoplatanus, Aruncus dioicus, Doronicum orientale, Epipactis purpurata, Galanthus nivalis, Hepatica nobilis, Lathyrus venetus, Lathyrus vernus, Melittis melissophyllum, Polystichum setiferum. Magas a generalisták aránya is $(50 \%)$, de a zavarástürőké és főleg a gyomoké alacsony, idegenhonos faj pedig egyáltalán nem fordul elő. A spektrumot összehasonlítva a közép-mecseki Kőszegi-forrás erdőrezervátum hasonló módon felmért aljnövényzetével, annál kicsit kedvezőbb képet kapunk. 


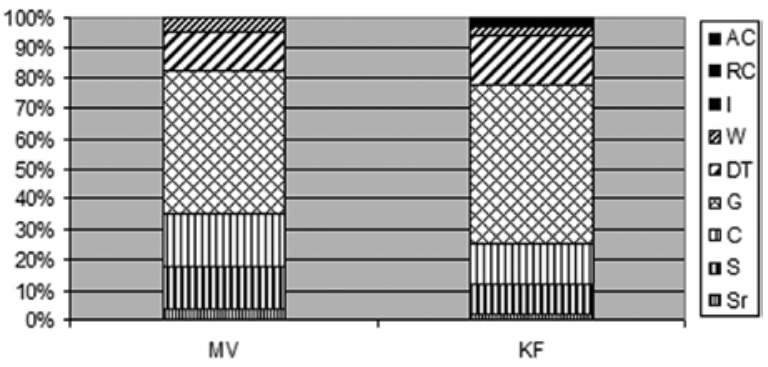

6. ábra: Szociális magatartás-típusok spektruma, összehasonlítva a Kőszegi-forrás erdőrezervátummal

A zavarástűrő és gyomfajok jól láthatóan a gerinc irányából nyomulnak be a területre (8. ábra). Ugyanakkor a specialista és ritka specialista fajok is elsősorban a gerinceken fordulnak elő, jelezve az ökotón (bükköstetőerdő, illetve rég felhagyott és 20 éve megzavart erdőrészletek) természetvédelmi értékét és egyben sebezhetőségét.

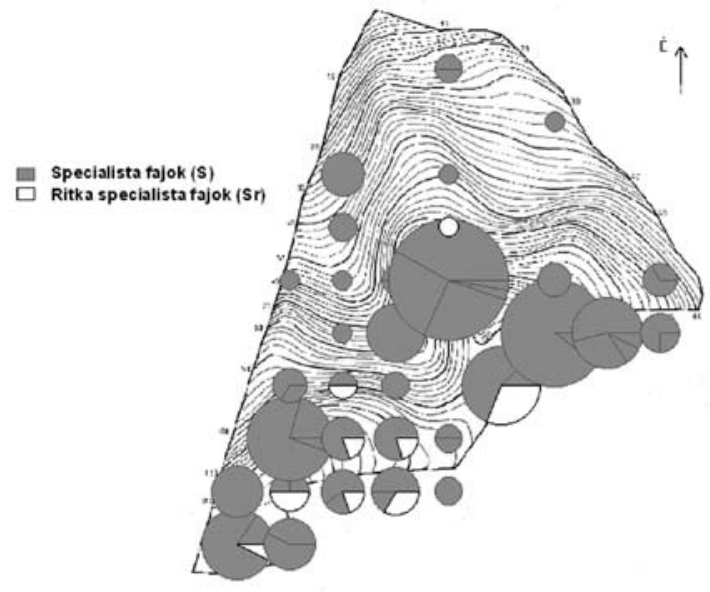

7. ábra: Specialista és ritka specialista fajok térbeli mintázata

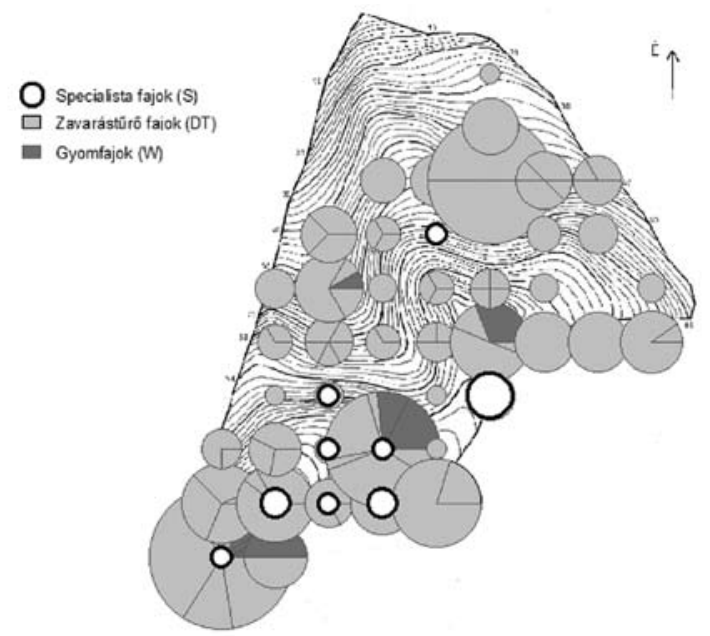

8. ábra: Zavarástürő és gyomfajok térbeli mintázata, összevetve a ritka specialistákkal

\section{Diverzitás mintázatok}

Az aljnövényzet diverzitásának térbeli mintázatát a Shannon indexszel, valamint az egységességgel (borítás/fajszám) jellemeztük (a térképeken csak az 5\%-nál nagyobb összborítású pontokat ábrázoltuk).

A Shannon-index térképe árnyaltabb képet mutat, mint a fajszám. A nagy diverzitású területek a völgyaljak és a lankásabb gerincközeli területek. Alacsony a diverzitás a nagyon meredek lejtőkön, föleg a mintavételi terület legalsó részén (árnyékolás is).

$A z$ egységesség a legnagyobb néhány gerinc-pontban (nagy Doronicum és Ruscus aculeatus állományok), valamint a középső rész „tipikus idős bükkösében”, ahol a tömeges típusalkotó fajok dominálnak, elsősorban. a sürü gyepet alkotó Carex pilosa, továbbá Galium odoratum, Galeobdolon luteum. Az első esetben a felnyíló erdő alatt megjelenő opportunista fajok foltszerü elszaporodása (Helleborus odorus, Ruscus aculeatus) a második esetben a kiegyensúlyozott, klimax állapotú erdő alacsony fajszáma (a termőhelynek legjobban megfelelő fajok itt jelentős kompetíciós előnyt élvezve kiszorították a többit) lehet a magyarázat.

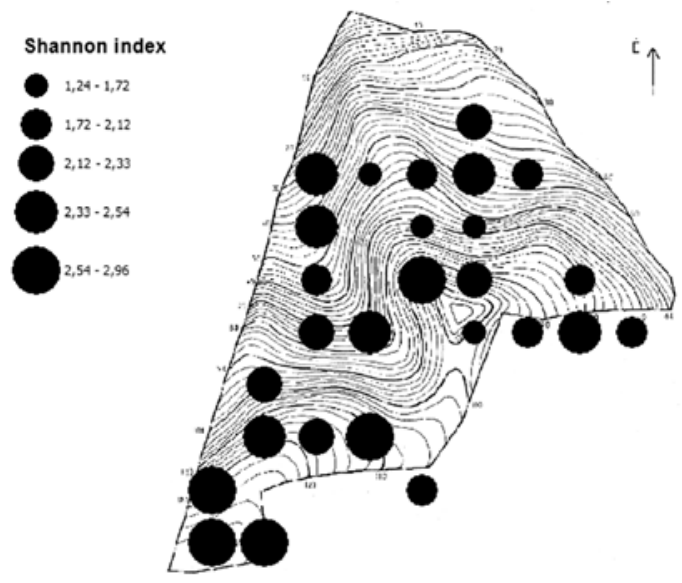

9. ábra: Shannon-diverzitás térbeli mintázata

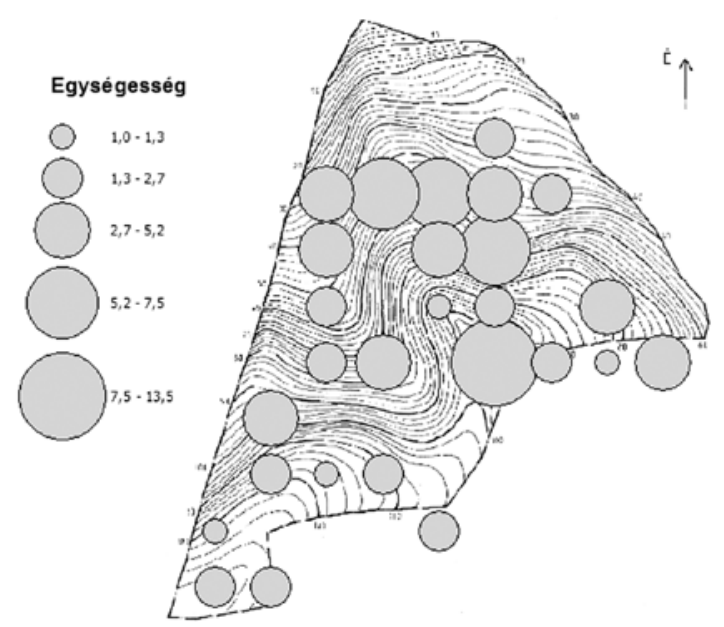

10. ábra: Egységesség térbeli mintázata 


\section{EGY ISMERETLEN „ÖSERDŐ” A KELET-MECSEKBEN: 25 ÉVE FELHAGYOTT BÜKKÖS ALJNÖVÉNYZETÉNEK TÉRBELI MINTÁZATAI}

\section{Összegzés, kitekintés}

A kelet-mecseki Várvölgyben található Magyaregregy 47A erdőrészlet aljnövényzete a fajgazdag idős mecseki bükkösök jellemzőit mutatja.

A 25 éves felhagyás hatása elsősorban a faállományban szembetűnő, elsősorban az idős, méretes fák kidőlése révén. A területen így már most is jelentős menynyiségü, jórészt vastag holtfa található, ami az erdei életközösség számos más tagjára gyakorolhat pozitív hatást. Ennek kutatása céljából a madárfajok részletes monitoringja indult el, de szóba került más biodiverzitáskomponensek (pl. kisemlösök, talajlakó gerinctelenek, mikorrhiza-gombák) vizsgálata is.

A természetes lékképződés és felújulás vizsgálata a közeli lékvágásokban folyó felújulási vizsgálatok kontrolljaként szolgálhat; ehhez szükséges az újulat más kuta- tásokkal összevethető módszerekkel történő állomány-, lék- és egyedalapú vizsgálata. A felújulás évtizedes léptékü értékeléséhez rendelkezésünkre állnak két egyedalapú faállomány-szerkezeti felmérés adatai.

Mindezek alapján kijelenthetjük, hogy a Mecsekerdő Zrt pécsváradi erdészete kárászi erdőgondnokságának kezelésében lévő Magyaregregy 47A erdőrészlet története, jelenlegi állapota, kutatottsága és a kiépült „erdőháló" alapján egyes erdörezervátumokhoz hasonló értékü színtere lehet a hazai bükkösök erdődinamikai kutatásának.

\section{Köszönetnyilvánítás}

Köszönjük a Mecsekerdő Zrt. sokrétű szakmai és gyakorlati segítségét.

\section{Irodalom}

2009. évi XXXVII. Törvény az erdöröl, az erdö védelméröl és az erdögazdálkodásról. - Magyar Közlöny 71/2009: 16273-16301.

BARTHA D. és EszTó P. 2002: Az erdőrezervátumok bemutatása az Országos Erdőállomány-adattár alapján. - In: Horváth $F$. és Borhidi A (eds): A hazai erdőrezervátum-kutatás célja, stratégiája és módszerei. Természetbúvár Alapítvány Kiadó, Bp. pp.60-82.

Boda R, Rozner Gy., CZirok A., Szivák I. \& Csabal Z. 2011: New data on the distribution of Cordulegaster heros Theischinger, 1979 in Mecsek mountains and its surroundings. - Acta Biologica Debrecina Supplementum Oecologica Hungarica 26: 21-28.

BORHIDI A. 1995: Social behaviour types, their naturalness and relative ecological indicator values of the higher plants of the Hungarian Flora. - Acta Botanica Hungarica 39:97-182.

BoRHIDI A. 2003: Magyarország növénytársulásai. Akadémiai, Bp., pp. 610.

Brang, P. 2005: Virgin forests as a knowledge source for Central European silviculture: reality or myth? - Forest.Snow and Landscape Research 79 (1/2): 19-32.

Csete S., Mányoki G., Ortmann-né Ajkal A., Partos K. és Bartha S. 2012 Kislékes szálalóvágás-kísérletek a Kelet-Mecsekben - egy most induló hosszútávú kutatás alapvetései. - Kitaibelia 171:89.

HORVÁTH F. és BORHIDI A. SZERK., 2002: A hazai erdörezervátum-kutatás célja, stratégiája és módszerei. Természetbúvár Alapitvány Kiadó, Bp, pp.289.

horváth F., Bidló A., Heil G., Király G., Kovács G., Mányoki G., Mázsa K. TANÁCS E., VEPERDI G. \& BöLÖNI J. 2012: Abandonment status and long-term monitoring of strict forest reserves in the Pannonian biogeographical region. - Plant Biosystems 146:1-12.

Kálmán Z., Soós N., Kovács T. Z., Szappanos D., Horváth O., Szivák I. és CSABAI Z. 2010: Vízibogarak és vízipoloskák faunisztikai adatai mecseki vízterekböl. - Hidrológiai Közlöny 90:50-52.

MAJeR A. 1962: Erdö- és termőhelytipológiai útmutató. OEF, Bp, pp. 330.

MÁtÉ G. \& VARGA A. 2011: Research of changing woodland areas in South-Hungary. - In: Frontiers in Historical Ecology Conference, WSL Birmensdorf-Zürich, Svájc, 2011
MÁTÉ G. 2009: A kultúrtáj változásának aspektusai Kárászon. In: Andrásfalvy Bertalan - Vargyas Gábor: Antropogén ökológia változások a Kárpát-medencében. Budapest, L'Harmattan. pp. 164-184.

Mauchart P., Méhes N., Deák Cs., Móra A., Szivák I. és Csabai Z. 2010 Kérészek, álkérészek és tegzesek faunisztikai adatai a mecseki vízterekböl. Hidrológiai Közlöny 90:100-102.

Méhes N., Kovács T. Z. és Szivák I. 2010: Diptera családok tér- és idöbeli elöfordulási sajátosságai mecseki patakokban lárva adatok alapján. - Acta Biologica Debrecina-Supplementum Oecologica Hungarica 21: 115-125.

Ódor P., BölöNI J. és STANDovÁR T. 2008: Az aljnövényzet vizsgálatának módszertani kidolgozása az erdörezervátumokban folyó hosszú távú vizsgálatsorozat keretében. - Kézirat. ER Archívum 2008/D009, MTA ÖK ÖBI, Vácrátót.

ORTMANN-NÉ AJKAI A. 2012: A spontán újulat makro- és mikrocönológiai viszonyai mecseki bükkösökben. - Kitaibelia 171:46

PARTOS, K. 2010: Örökerdö a Keleti-Mecsekben. - Erdészeti Lapok CXLV(6):194-195

PÁsztor E. és Oborny B. (eds) 2007: Ökológia. Nemzeti Tankönyvkiadó, Bp., pp. 420.

SIROK A. 2011: Diverzitás vizsgálatok felhagyott bükkösökben. - Szakdolgozat. PTE TTK Környezettudományi Intézet, pp. 61.

Sомосуı Z. 2002: Az erdörezervátumokban folytatandó kutatások általános célkitüzései. - In: Horváth F. és Borhidi A.: A hazai erdőrezervátum-kutatás célja, stratégiája és módszerei. Természetbúvár Alapitvány Kiadó, Bp. pp. 83-87.

Szivák I., Deák Cs., Kálmán Z., Soós N., Mauchart P., Lökkös A., Rozner Gy., Móra A. \& Csabal Z. 2010: Contribution to the aquatic macroinvertebrate fauna of the Mountains Mecsek with the first record of Limnius opacus P.J.W. Müller, 1806 in Hungary. - Acta Biologica Debrecina-Supplementum Oecologica Hungarica 21:197-222.

Tóth István Zs., Ortmann-né Ajkal A., Partos K., Sirok A., Nagy D. és KULCSÁR P. 2012: 25 éve felhagyott mecseki bükkös aljnövényzeti vizsgálata. - Kitaibelia 171:60. 


\title{
A scarcely known old-growth forest in Eastern Mecsek hills: Spatial patterns of the herb layer of a beech forest abandoned 25 years ago.
}

\author{
ADRIENNE ORTMANN-NÉ AJKAI, ISTVÁN ZSOLT TÓTH, ATTILA SIROK, DÁNIEL NAGY, \\ PÉTER KULCSÁR, KÁLMÁN PARTOS
}

Summary

A 130-years old beech forest stand in Eastern Mecsek hills (Southern Hungary), abandoned 2225 years ago, provides excellent opportunities for the study of spontaneous forest dynamics. In 2010 intensive studies started, iniciated by Mecsekerdő Zrt: repeating an individuum-based tree-stand survey of 1986-87, a grid-based herb layer survey according to the Forest Reserve Protocol $(50 \times 50 \mathrm{~m}$ grid) and bird monitoring. Results of the herb layer study is presented here.

The forest is Helleboro odori - Fagetum, with transitions towards ravine and scree forests. Herb layer cover is medium to high, with mostly Fagetalia elements. Submediterranean species: Tamus communis, Ruscus aculeatus, R. hypoglossum, Helleborus odorus, Lathyrus venetus, Asperula taurina are also characteristic. Forest type indicators are: Galium odoratum, Galeobdolon luteum; on the steepest and more rocky parts Melica uniflora, Mercurialis perennis and Festuca drymeia; and Carex pilosa closest to the stream. 95 species, amongst them 14 protected ones were found, most of them in the hillside-hilltop ecotone. Most important are the more thousand exemplars of Doronicum orientale reported only from two places of Mecsek Hills before. Further protected species are: Aruncus dioicus, Asperula taurina subsp. leucanthera, Cephalanthera damasonium, Dryopteris dilatata, Epipactis purpurata, Epipactis helleborine, Galanthus nivalis, Polystichum setiferum, Helleborus odorus, Hepatica nobilis, Lathyrus venetus, Ruscus hypoglossum, Ruscus aculeatus, Tamus communis. Other species worth to mention are: Festuca drymeia, Veronica montana.

More than $30 \%$ percentage of specialist and competitor species indicates a very good naturalness state, comparable with forest reserves. 